\title{
Kahalalide Derivatives from the \\ Indian Sacoglossan Mollusc Elysia grandifolia
}

(Supporting Information)

Mohamed Ashour, ${ }^{\ddagger}, \dagger$ RuAngelie Edrada, ${ }^{\ddagger}$ Rainer Ebel, ${ }^{\ddagger}$ Victor Wray, ${ }^{\S}$ Wim Wätjen,

K. Padmakumar, ${ }^{\perp}$ Werner E. G. Müller, ${ }^{\Delta}$ Wen Han Lin $^{\circ}$ and Peter Proksch ${ }^{\ddagger *}$

Institut für Pharmazeutische Biologie und Biotechnologie, Heinrich-Heine-Universität Düsseldorf, Universitätsstr. 1, Geb. 26.23, 40225 Düsseldorf, Germany. Department of Structural Biology, Helmholtz Centre for Infection Research, Inhoffenstrasse 7, 38124 Braunschweig, Germany. Institut für Toxikologie, Heinrich-Heine-Universiät Düsseldorf, Universitätsstr. 1, Geb. 22.21, 40225 Düsseldorf, Germany. Centre for Marine Biodiversity, Department of Aquatic Biology and Fisheries, University of Kerala, Trivandrum695581, India. Institut für Physiologische Chemie und Pathobiochemie, Johannes-GutenbergUniversität, Duesbergweg 6, 55128 Mainz, Germany. National Research Laboratory of Natural and Biomimetic Drugs, Peking University, 100083 Beijing, China.

\section{Cell cultures}

L5178Y mouse lymphoma cells were grown in Eagle's minimal essential medium supplemented with $10 \%$ horse serum in roller tube culture. The H4IIE-cell line was grown in a DMEM-medium with $10 \%$ fetal bovine serum, while HELA, PC12, and MCF-7 cells were grown in RPMI 1640 medium supplemented with non-essential amino acids, sodium pyruvate, $10 \mu \mathrm{g} / \mathrm{mL}$ insulin and $10 \%$ fetal bovine serum. The cell culture media contained $100 \mathrm{units} / \mathrm{mL}$ penicillin and $100 \mu \mathrm{g} / \mathrm{mL}$ streptomycin and was changed twice per week. The cells were maintained in a humidified atmosphere at $37{ }^{\circ} \mathrm{C}$ with $5 \% \mathrm{CO}_{2}$. 


\section{Determination of cytotoxicity}

MCF-7 cells, PC12, HeLa, L1578Y, and H4IIE were plated on 96-multiwell plates with 50,000 cells/well. The cells were allowed to attach for $24 \mathrm{~h}$ and then treated with different concentrations of kahalalides for $24 \mathrm{~h}$. After this treatment the medium was changed and the cells were incubated for $3 \mathrm{~h}$ under cell culture conditions with $20 \mu \mathrm{g} / \mathrm{mL}$ MTT (3-(4,5dimethyl-2-thiazolyl)-2,5-diphenyl-2H-tetrazolium bromide). The conversion of the tetrazolium salt MTT to a colored formazan by mitochondrial dehydrogenases was determined as a marker of cell viability. ${ }^{34,35}$ After incubation, the cells were fixed on the plate with an aq. solution containing $1 \%$ formaldehyde and $1 \% \mathrm{CaCl}_{2}$ and then lysed with 95:5 i-PrOH-formic acid. The concentration of reduced MTT as a marker for cell viability was measured photometrically at $560 \mathrm{~nm}$.

\section{Statistics}

Data are given as mean \pm S.E.M. of 3 independent experiments. The significance of changes in the test responses was assessed using a one-way ANOVA followed by LSD test (Analyse-it, Leeds, UK); differences were considered significant at $\mathrm{p}<0.05$. 